ISSN: $1412-8837$

\title{
KORELASI FAKTOR SOSIAL EKONOMI DENGAN PENERIMAAN USAHA PERKEBUNAN KELAPA SAWIT RAKYAT DI DESA NANTI AGUNG, KECAMATAN ILIR TALO, KABUPATEN SELUMA
}

\author{
(CORRELATION BETWEEN SOCIAL ECONOMIC FACTORS AND \\ SMALLHOLDER PALM OIL PLATATION REVENUE IN NANTI \\ AGUNG VILLANG, SUBDISCTRICT OF ILIR TALO, DISTRICT OF \\ SELUMA)
}

\author{
Helvera Ivana, Basuki Sigit Priyono, Reflis \\ Jurusan Sosial Ekonomi Pertanian Fakultas Pertanian Universitas Bengkulu
}

\begin{abstract}
The study of the correlation between social economy factors and the acceptance level of the smallholder palm plantations is conducted in Nanti Agung Village, Ilir Talo Subdistrict Seluma Regency. The aims of the study are to investigate the accepatance level of the smallholder palm plantations and to investigate the correlation between social economic factors and the acceptance of the citizenry palm plantations. The amount of 71 farmers that have main work in palm plantations area are taken by census. Data are analyzed by chi square $\left(X^{2}\right)$. The study show that the acceptance level of smallholder palm farmers is in medium/high enough category. Social-economy factors that obviously correlated toward the acceptance level of the smallholder palm plantations are farmer's age, formal education, the number of workers, and wide area. The other way, the factors that are not correlated toward the acceptance level of smallholder palm plantation farmers are non formal education, motivation, and experinces in plantations working.
\end{abstract}

Keywords: the acceptance, citizenry palm plantation, socio-economy factors

\section{PENDAHULUAN}

Pembangunan pertanian di Indonesia sebagai bagian dari pembangunan nasional yang berkelanjutan, berbasis industri dan berorientasi bisnis bertujuan untuk: meningkatkan pendapatan dan taraf hidup petani, memperluas lapangan kerja dan kesempatan berusaha, menunjang pembangunan industri, meningkatkan ekspor serta mendukung pembangunan daerah. Dalam perdagangan internasional, komoditi kelapa sawit mempunyai peluang atau memiliki prospek ke depan yang gemilang dan terus meningkat yang 
mendorong pemerintah Indonesia untuk memacu pengembangan areal perkebunan kelapa sawit.

Bagi Indonesia tanaman kelapa sawit memiliki arti penting bagi pembangunan perkebunan nasional. Selain mampu menciptakan kesempatan kerja yang mengarah pada kesejahteraan masyarakat, juga sebagai sumber perolehan devisa negara. Meskipun pasar dunia saat ini lebih banyak meminta Indonesia mengekspor CPO sebesar 90\% dibandingkan dengan produk turunannya yakni 10\% (Pardamean, 2008).

Di Desa Nanti Agung, Kec. Ilir Talo, Kab. Seluma, Prov. Bengkulu perkebunan kelapa sawit telah cukup lama diusahakan. Kebun kelapa sawitnya sedang memasuki usia produktivitas yaitu umur 5 sampai 10 tahun. Menurut Soekartawi (2003), produksi pertanian (termasuk kelapa sawit) yang maksimum, dipengaruhi oleh faktor-faktor produksi yang terdiri dari empat unsur pokok, yaitu: tanah atau lahan, tenaga kerja, modal dan manajemen, (Soekartawi, 2003).

Besar kecilnya produksi kelapa sawit akan mempengaruhi besar kecilnya penerimaan usahatani yang dilakukan oleh para petani. Faktor-faktor yang melekat pada diri petani kelapa sawit pada umumnya turut memberikan pengaruh terhadap besar kecilnya produk kelapa sawit yang diusahakan dan penerimaan dari kegiatan usaha kelapa sawit..

Berdasarkan hal tersebut, maka tujuan penelitian ini adalah untuk menghitung tingkat penerimaan usaha perkebunan kelapa sawit rakyat di Desa Nanti Agung Kec. Ilir Talo, Kab. Seluma dan untuk mengkaji korelasi faktor sosial ekonomi dengan penerimaan usaha perkebunan kelapa sawit rakyat.

\section{METODE PENELITIAN}

\section{Lokasi, Data dan Responden}

Penelitian ini dilakukan di Desa Nanti Agung, Kec. Ilir Talo, Kab. Seluma karena cukup banyak penduduk yang berkebun kelapa sawit selama 10 tahun terakhir. Data yang dikumpulkan adalah data primer dan data sekunder. Data primer diperoleh secara langsung dari responden melalui wawancara terstruktur dengan menggunakan kuesioner yang sudah dipersiapkan, sedangkan data sekunder diperoleh dari pustaka atau literatur-literatur dan instansi atau lembaga yang terkait dengan penelitian ini.

Populasi penelitian adalah petani yang mempunyai pekerjaan pokok di bidang usaha perkebunan kelapa sawit dan tinggal di lokasi penelitian yang terpilih. Seluruh petani yang memiliki tanaman kelapa sawit yang sedang memasuki masa produktivitas yaitu 5 sampai 10 tahun sebanyak 71 orang diambil secara sensus ( Nazir 1998). 


\section{Analisis Data}

Untuk menghitung penerimaan usaha perkebunan kelapa sawit ini digunakan analisis penerimaan usahatani (Soekartawi,2002). Penerimaan usaha kelapa sawit adalah perkalian antara produksi yang diperoleh (2 kali panen per bulan) dengan dengan harga jualnya. Pernyataan ini dapat dituliskan sebagai berikut:

$$
\mathrm{TR}=\mathrm{Y} . \mathrm{Py}
$$

dimana TR adalah total revenue (total penerimaan), Y adalah produksi yang diperoleh dalam suatu usahatani, dan Py adalah harga produk.

Selanjutnya nilai penerimaan usaha perkebunan kelapa sawit ini akan dikelompokkan menjadi tiga kategori, yaitu: rendah jika $(<$ rerata penerimaan $1 / 2$ Stdev), sedang jika (rerata penerimaan $-1 / 2$ Stdev $\leq \mathrm{Y} \leq$ rerata penerimaan $+1 / 2$ Stdev, dan tinggi jika (> rerata penerimaan $+1 / 2$ Stdev).

Untuk mengkaji hubungan antara faktor-faktor sosial ekonomi dan tingkat penerimaan petani kelapa sawit maka digunakan analisis statistik non parametik yaitu dengan menggunakan analisis chi square $\left(\mathrm{x}^{2}\right)$ yaitu suatu metode pengujian untuk melihat ada/tidaknya hubungan yang signifikan terhadap beberapa variabel yang diamati (Djarwanto, 1985 dan Siegel, 1997), dengan formula sebagai berikut:

$$
X^{2}=\Sigma \frac{(f o-f e)^{2}}{f e}
$$

dimana : $f_{\mathrm{o}}=$ frekuensi hasil pengamatan, $f \mathrm{e}=$ frekuensi yang diharapkan, dan $\sum=$ jumlah frekuensi. Untuk menguji signifikansinya dilakukan dengan: Bila $\mathrm{X}^{2}$ hitung $\geq X^{2}$ tabel, maka Ho ditolak atau Ha diterima. Artinya ada hubungan yang positif dan signifikan antara variabel pengaruh $(\mathrm{X} i)$ dengan variabel terpengaruh ( $\mathrm{Y}$ ) dan Bila $\mathrm{X}^{2}$ hitung $<\mathrm{X}^{2}$ tabel, maka Ho diterima atau Ha ditolak. Artinya tidak ada hubungan yang signifikan antara variabel pengaruh $(X)$ dengan variabel terpengaruh $(\mathrm{Y})$.

Selanjutnya untuk mengetahui besarnya derajat keeratan digunakan rumus koefisien kontingensi (C) sebagai berikut (Sugiyono, 1999):

$$
C=\sqrt{\frac{X^{2}}{n+X^{2}}}
$$

dimana: $C=$ Koefisien Kontingensi, $X^{2}=C h i$ square, dan $n=J u m l a h$ Sampel

Untuk dapat memberi interpretasi terhadap kuat tidaknya hubungan variabel yang dikorelasikan, maka nilai $\mathrm{C}$ dibandingkan dengan nilai koefisien Cmax, dimana nilai Cmax dapat dihitung dengan rumus (Siegel, 1997):

$$
C_{\text {maks }}=\sqrt{\frac{k-1}{k}}
$$


dimana $\mathrm{k}$ adalah jumlah kolom atau jumlah baris kecil. Ketentuan membandingkan nilai $\mathrm{C}$ dengan $\mathrm{Cmax}$, adalah sebagai berikut: Bila $\mathrm{C}<1 / 3$ Cmax maka derajat hubungan antar variabel lemah, Bila 1/3 $\mathrm{Cmax} \leq \mathrm{C} \leq 2 / 3$ Cmax maka derajat hubungan antar variabel sedang, dan Bila $\mathrm{C}>2 / 3 \mathrm{Cmax}$ maka derajat hubungan antar variabel kuat.

\section{HASIL DAN PEMBAHASAN}

\section{Penerimaan Usaha Perkebunan Kelapa Sawit}

Analisis penerimaan usaha perkebunan kelapa sawit ini digunakan analisis penerimaan usahatani yang diadopsi dari Soekartawi (2002). Tingkat penerimaan usaha perkebunan kelapa sawit rakyat di Desa Nanti Agung diperlihatkan pada tabel berikut.

Tabel 1. Penerimaan usaha perkebunan kelapa sawit rakyat

\begin{tabular}{lccc}
\hline $\begin{array}{c}\text { Penerimaan } \\
\text { (Rp/bulan) }\end{array}$ & $\begin{array}{c}\text { Jumlah } \\
\text { (Jiwa) }\end{array}$ & $\begin{array}{c}\text { Persentase } \\
(\%)\end{array}$ & $\begin{array}{c}\text { Rerata } \\
(\text { Rp } / \text { bulan })\end{array}$ \\
\hline$<1.161 .299$ (rendah) & 26 & 36.6 & \\
$1.161 .299-2.051 .750$ (sedang) & 33 & 46,5 & 1.606 .525 \\
$>2.051 .750$ (tinggi) & 12 & 16,9 & \\
\hline
\end{tabular}

Sumber: Data primer diolah, 2011

Berdasarkan hasil yang ditunjukkan Tabel 1 diketahui bahwa rata-rata penerimaan yang diperoleh petani dari usaha kebun kelapa sawitnya sebesar Rp 1.606.525/bulan. Sebanyak 46,5\% mempunyai penerimaan dalam kategori sedang dan $36,6 \%$ dalam kategori rendah penerimaannya. Hal ini menunjukkan bahwa para petani kelapa sawit rakyat di desa ini mempunyai penerimaan yang cukup rendah. Berdasarkan standar penerimaan yang dikategorikan pemerintah provinsi Bengkulu atau upah minimum regional (UMR) yaitu sebesar Rp 950.000/bulan, maka penerimaan para petani kelapa sawit rakyat di desa ini masih tergolong tinggi, sehingga para petani mampu memenuhi kebutuhan hidupnya sehar-hari meskipun relatif sederhana.

\section{Faktor-faktor yang Berhubungan dengan Penerimaan Usaha Perkebunan Kelapa Sawit}

Untuk melihat hubungan variabel-variabel bebas dengan penerimaan usaha perkebunan kelapa sawit rakyat maka digunakan analisis statistik non parametrik chi square $\left(\mathrm{X}^{2}\right)$ dengan program SPSS. Untuk melihat derajat hubungan masing-masing variabel bebas dengan penerimaan usaha perkebunan kelapa sawit rakyat digunakan koefisien kontingensi (C). Hasil estimasi chi square $\left(\mathrm{X}^{2}\right)$ dan nilai koefisien kontingensi (C) disajikan pada Tabel 2 berikut. 
Tabel 2. Hasil analisis Chi square $\left(X^{2}\right)$ dan Koefisien Kontingensi (C)

\begin{tabular}{llcc}
\hline No. & \multicolumn{1}{c}{ Variabel-variabel yang Dikorelasikan } & $\begin{array}{c}\text { Chi square } \\
\left(\mathrm{X}^{2}\right)\end{array}$ & $\begin{array}{c}\text { Koefisien } \\
\text { Kontingensi } \\
(\mathrm{C})\end{array}$ \\
\hline 1 & Umur (X1) & $18,63^{*}$ & $0,34^{2}$ \\
2 & Pendidikan formal (X2) & $25,76^{*}$ & $0,45^{1}$ \\
3 & Pendidikan non formal (X3) & - & - \\
4 & Motivasi kerja (X4) & 8,9 & $0,13^{3}$ \\
5 & Pengalaman usaha (X5) & 1,1 & $0,10^{3}$ \\
6 & Jumlah tenaga kerja (X6) & $47,81^{*}$ & $0,40^{1}$ \\
7 & Luas lahan (X7) & $41,49^{*}$ & $0,46^{1}$ \\
\hline
\end{tabular}

Sumber: Data primer diolah, 2011

Keterangan:

$\left(^{*}\right)$ Berhubungan secara signifikan pada uji $\left(X^{2}\right)$ tabel $($ df $4: 0,05)=9,488$

(1) Derajat hubungan kuat pada uji harga $>2 / 3 \operatorname{Cmaks}(0,36)$

(2) Derajat hubungan sedang pada uji harga $0,18 \leq \mathrm{Cmaks} \leq 0,36$

(3) Derajat hubungan lemah pada uji harga $<1 / 3 \mathrm{Cmaks}(0,18)$

Hasil analisis memberikan indikasi bahwa variabel umur (X1), pendidikan formal (X2), tenaga kerja (X6) dan luas lahan (X7) berhubungan secara signifikan dengan penerimaan usaha perkebunan petani kelapa sawit rakyat di desa Nanti Agung. Sementara itu, variabel lainnya tidak berhubungan secara signifikan dengan penerimaan usaha perkebunan petani kelapa sawit rakyat yakni pendidikan non formal (X3), motivasi kerja (X4) dan pengalaman usaha (X5). Hasil uji koefisien kontingensi (C) menunjukkan bahwa variabel pendidikan formal (X2), tenaga kerja (X6) dan luas lahan (X3), mempunyai derajat hubungan sangat kuat dengan erat penerimaan usaha perkebunan petani kelapa sawit rakyat, dimana besarnya nilai Cmaks adalah 0,47.

Analisis korelasi masing-masing variabel bebas dengan penerimaan usaha perkebunan kelapa sawit rakyat disajaikan sebagai berikut:

\section{Umur petani}

Hasil uji statistik dengan chi square diperoleh nilai $X^{2}$ hitung=18,63 yang lebih besar dari $X^{2}$ tabel $(9,488)$, artinya umur petani berhubungan secara signifikan dengan penerimaan usaha perkebunan kelapa sawit rakyat. Sementara nilai koefisien kontingensi $(C)=0,34$ yang berarti derajat hubungan antara umur petani dengan penerimaan usaha perkebunan kelapa sawit rakyat termasuk kategori sedang.

Hal ini dapat terjadi karena dengan umur petani yang cukup matang maka dapat mempengaruhi kemampuan dan cara berpikirnya, sehingga mampu meningkatkan hasil produksi tanaman kelapa sawitnya dan pada akhirnya meningkatkan penerimaannya. Hasil penelitian ini sesuai dengan hasil penelitian Iswanto (2001), variabel umur berkorelasi secra nyata dengan tingkat 
penerimaan. Para petani yang berada pada usia produktif terbukti mempunyai kemampuan kerja yang lebih efektif. Cara kerja yang lebih efektif memberikan hasil yang lebih maksimal.

\section{Pendidikan Formal}

Hasil uji statistik dengan chi square diperoleh nilai $X^{2}$ hitung $=25,76$ yang lebih besar dari $\mathrm{X}^{2}$ tabel $(9,488)$ artinya pendidikan formal berhubungan secara signifikan dengan penerimaan usaha perkebunan kelapa sawit rakyat. Sementara nilai koefisien kontingensi $(C)=0,45$ yang berarti derajat hubungan pendidikan formal petani terhadap penerimaan usaha perkebunan kelapa sawit rakyat berada dalam kategori kuat. Artinya semakin tinggi pendidikan formal maka tingkat penerimaan usaha perkebunan kelapa sawit para petani juga tinggi.

Pendidikan formal berfungsi menentukan kemampuan petani dalam menyerap suatu inovasi, meningkatkan keterampilan, kecerdasan, dan kepandaian petani untuk mengelola usaha perkebunan kelapa sawitnya. Dengan demikian tingkat penerimaan petani kelapa sawit rakyat diharapkan juga meningkat seiring dengan peningkatan pendidikan formalnya. Pendidikan yang tinggi akan membuat pola pikir para petani menjadi lebih baik, sehingga akan mempengaruhi semua keputusan yang akan diambilnya dalam mengadopsi suatu teknologi untuk mengelola usahatani padi yang diusahakannya.

\section{Pendidikan Non Formal}

Pendidikan non formal juga merupakan salah satu faktor yang diduga berhubungan dengan penerimaan usaha perkebunan kelapa sawit rakyat. Pendidikan non formal menunjukkan frekuensi para petani kelapa sawit dalam mengikuti kegiatan belajar non formal, seperti kegiatan pelatihan, kursus dan atau penyuluhan. Namun demikian, variabel pendidikan non formal tidak dilakukan analisis Chi-Square, Coefisien Contingensi serta Cmaks dengan tingkat penerimaan dari usaha perkebunan kelapa sawit, karena berdasarkan hasil penelitian di lapangan memperlihatkan bahwa hanya 3 pertani responden yang pernah mengikuti pendidikan non formal. Dengan demikian tidak ada data yang bisa dianalisa dengan menggunakan uji statistik.

\section{Motivasi}

Hasil uji statistik diperoleh nilai $\mathrm{X}^{2}$ hitung $=8,9$ lebih kecil dari $\mathrm{X}^{2}$ tabel $(9,488)$ artinya motivasi kerja petani tidak berkorelasi secara signifikan dengan penerimaan usaha perkebunan kelapa sawit rakyat. Begitu juga pada nilai koefisien kontingensi $(C)=0,13$ artinya derajat hubungan motivasi kerja petani dengan penerimaan usaha perkebunan kelapa sawit rakyat berada dalam kategori lemah. 
Tidak nyatanya hubungan motivasi kerja petani dengan tingkat penerimaan usaha perkebunan kelapa sawit rakyat karena dalam melakukan usaha perkebunan kelapa sawit yang paling diperlukan adalah pengelolaan atau perawatan yang baik. Sedangkan dalam pengelolaan atau perawatan perkebunan kelapa sawit ini tidak harus pemilik perkebunan kelapa sawit itu sendiri. Pengelolaan atau perawatan kelapa sawit tersebut memang sudah menjadi hal pokok yang harus dilakukan agar hasil produksinya maksimal.

Hasil penelitian ini tidak sejalan dengan hasil penelitian Iswanto (2001) yang menyatakan bahwa motivasi berkorelasi secara nyata dengan penerimaan petani usahatani padi di Desa Palak Siring, Kec. Perwakilan Kedurang, Kab. Bengkulu Selatan. Penerimaan hasil tanaman padinya mampu memenuhi kebutuhan hidupnya, sehingga memberikan dorongan para petani lebih bersemangat dalam melakukan usahatani padi.

\section{Pengalaman Usaha Perkebunan}

Hasil uji statistik dengan chi square diperoleh nilai $X^{2}$ hitung=1,10 yang lebih kecil dari $\mathrm{X}^{2}$ tabel $(9,488)$ artinya pengalaman usaha perkebunan tidak berhubungan secara signifikan dengan penerimaan usaha perkebunan kelapa sawit rakyat. Sementara nilai koefisien kontingensi $(C)=0,1$ nilai ini lebih kecil dari harga $1 / 3$ Cmaks $(0,18)$ yang berarti derajat hubungan antara pengalaman usaha perkebunan dan penerimaan usaha perkebunan kelapa sawit rakyat adalah lemah.

Hal ini memberikan indikasi bahwa tingkat penerimaan petani kelapa sawit rakyat tidak tergantung dari tingkat pengalaman usaha perkebunannya. Pengalaman usaha perkebunan kelapa sawit hanya membantu para petani untuk menghadapi dan mengatasi setiap kesulitan dan hambatan yang dialami dari setiap kegiatan usaha. Sementara tingkat penerimaan tidak hanya dipengaruhi oleh hasil produksi yang tinggi yang dapat diperoleh dengan mengelola tanaman kelapa sawit secara tepat, tetapi juga dipengaruhi oleh harga tandan buah sawit (TBS) pada saat itu.

Hasil penelitian ini tidak sejalan dengan hasil penelitian Hermanto (2004), yang menyatakan bahwa semakin tinggi atau banyak pengalaman kerja para petani karet peserta PIR dan non PIR (kasus di sekitar PIR karet Kec. Pondok Kelapa), maka akan semakin baik dan mempengaruhi tingkat pendapatan para petani.

\section{Jumlah Tenaga Kerja}

Jumlah tenaga kerja dalam penelitian ini adalah jumlah tenaga kerja, baik dari dalam keluarga maupun tenaga kerja dari luar keluarga, yang terlibat dalam kegiatan usaha perkebunan kelapa sawit rakyat. Hasil uji statistik dengan chi square diperoleh nilai $X^{2}$ hitung $=47,19$ lebih besar dari $X^{2}$ tabel $(9,488)$ artinya jumlah tenaga kerja berhubungan secara signifikan dengan penerimaan usaha perkebunan kelapa sawit rakyat. Sementara nilai koefisien kontingensi $(C)=0,40$ 
yang berarti derajat hubungan antara jumlah tenaga kerja dan penerimaan usaha perkebunan kelapa sawit rakyat berada dalam kategori kuat. Pengamatan di lapangan menunjukkan bahwa variabel jumlah tenaga kerja berkorelasi sangat kuat dengan penerimaan usaha perkebunan kelapa sawit rakyat. Hal ini dikarenakan semakin banyak tenaga yang dicurahkan maka semakin baik pertumbuhan tanaman kelapa sawitnya, sehingga akan berpengaruh terhadap peningkatan tandan buah segar yang dihasilkan dan alkhirnya akan meningkatkan penerimaannya.

\section{Luas Lahan}

Luas lahan adalah total lahan yang digarap oleh para petani menjadi lahan usaha perkebunan kelapa sawit. Hasil uji statistik dengan chi square diperoleh nilai $X^{2}$ hitung=41,49 lebih besar dari X2tabel $(9,488)$, artinya luas lahan usaha perkebunan kelapa sawit berhubungan secara signifikan dengan penerimaan usaha perkebunan kelapa sawit rakyat. Sementara nilai koefisien kontingensi $(C)=0,46$ dimana nilai ini lebih besar dari nilai $2 / 3$ Cmaks $(0,36)$ yang berarti derajat hubungan antara luas lahan perkebunan kelapa sawit dan penerimaan usaha perkebunan kelapa sawit rakyat berada pada kategori kuat. Hal ini dapat dikatakan bahwa penerimaan petani kelapa sawit rakyat sangat tergantung dari luas lahan usaha perkebunannya. Semakin luas lahan usaha perkebunan kelapa sawit yang dimiliki dan diusahakan para petani, maka semakin banyak pohon kelapa sawit yang bisa ditanam. Semakin banyak pohon kelapa sawit yang ditanam maka semakin banyak pohon kelapa sawit yang diharapkan mampu berproduksi. Semakin tinggi produksi maka penerimaan juga akan semakin tinggi. Hermanto (2003) menyatakan bahwa semakin luas lahan usahatani yang digarap ternyata mampu menghasilkan produksi yang lebih banyak dan total penerimaan yang didapatkan.

\section{SIMPULAN DAN SARAN}

\section{Simpulan}

1. Tingkat penerimaan para petani kelapa sawit rakyat di Desa Nanti Agung, Kecamatan Ilir Talo, Kabupaten Seluma sebesar Rp. 1.606.525, 00 per bulan termasuk dalam ketegori sedang.

2. Faktor-faktor sosial ekonomi yang berhubungan secara signifikan dengan tingkat penerimaan petani dari usaha perkebunan kelapa sawit rakyat adalah umur petani, pendidikan formal, jumlah tenaga kerja, dan luas lahan. Sementara, faktor-faktor yang tidak berhubungan secara signifikan adalah pendidikan non formal, motivasi kerja, dan pengalaman usaha perkebunan. 


\section{Saran}

Pemerintah setempat sebaiknya lebih sering melakukan kegiatan penyuluhan tentang berbagai aspek yang berkaitan dengan perkebunan kelapa sawit agar usaha yang dilakukan para petani menjadi lebih maju, lebih meningkat produksinya, dan lebih banyak penerimaan yang didapatkannya.

\section{DAFTAR PUSTAKA}

Djarwanto. 1985. Statistik Nonparametrik. BPFE, Yogyakarta.

Hermanto, E. 2004. Studi Faktor Sosial Ekonomi yang Mempengaruhi Pendapatan Petani Karet Peserta PIR dan Non PIR (Kasus di sekitar PIR karet Kec. Pondok Kelapa). Jurusan Sosial Ekonomi Pertanian, Fakultas Pertanian. Universitas Bengkulu. Skripsi (Tidak dipublikasikan).

Iswanto, C. 2001. Hubungan Faktor Sosial Ekonomi dan Psikologi dengan Tingkat Penerimaan Usahatani Padi (Di Desa Palak Siring Kecamatan Perwakilan Kedurang). Jurusan Sosial Ekonomi Pertanian, Fakultas Pertanian. Universitas Bengkulu. Skripsi (Tidak dipublikasikan).

Nazir, M. 1998. Metode Penelitian. Ghalia Indonesia, Jakarta.

Pardamean, M. 2008. Panduan Lengkap Pengelolaan Kebun dan Pabrik Kelapa Sawit. PT. Agromedia Pustaka, Jakarta.

Siegel, S. 1997. Statistik Non Parametrik. Gramedia, Jakarta

Soekartawi. 2002. Prinsip Dasar Ekonomi Pertanian: Teori dan Aplikasi. PT. Raja Grafindo Persada, Jakarta. . 2003. Teori Ekonomi Produksi. PT. Raja Grafindo Persada, Jakarta.

Sugiyono. 1999. Statistik Nonparametrik untuk Penelitian. Alfabeta, Bandung. 